\title{
The Impact of Leadership, Motivation, Discipline, and Wages on The Performance of Sharia Bank Employees
}

\author{
Heni Noviarita \\ Universitas Islam Negeri Raden Intan Lampung, Indonesia \\ email: heninoviarita@radenintan.ac.id
}

Roslee bin Ahmad

Universiti Sains Islam Malaysia, Malaysia

email: rosmad2020@gmail.com

\section{Idzam Fautau}

Universitas Islam Negeri Sunan Gunung Djati, Indonesia

email: idzamfautanu@uinsgd.ac.id

\begin{abstract}
The development of Islamic Banks increased rapidly. Based on assets, profitability, market share, and others. They were followed by internal management, such as an expansion of the facilities and services. On the other hand, considering Islamic Banks' human resources is very important in realizing the vision and mission. As a result, they must be improving the worker's performance on the goals. This research used a quantitative approach with the independent variable are leadership, working discipline, motivation, and wages. The dependent variable used in this research is employee performance. The result showed that leadership, working discipline, motivation, and wages significantly affect the employee enterprise. It can be seen from the magnitude of $t$ count of $45.804>t$ table of 2.51 with a significance (sig) of $0.000<0.05$. Simultaneously critical in the leadership thorough giving higher wage and the reward encouraged workers' motivation, discipline to increase workers' performance. As a result, those variables can improve employee performance to achieve a manner together in Bank BRI Syariah Tugumulyo Branch, Bandar Lampung, South Sumatra. The conclusion stated that the independent variables affected the workers' enterprise. Therefore, as a result, these models are very suitable for improving banks' workers to achieve their goals.
\end{abstract}

Keywords: Leadership; Motivation; Working Discipline; Wages; Performance

Abstrak: Perkembangan Bank Syariah meningkat pesat. Berdasarkan aset, profitabilitas, pangsa pasar, dan lain-lain. Disusul dengan manajemen internal, seperti perluasan fasilitas dan layanan. Di sisi lain, mengingat sumber daya manusia Bank Syariah sangat penting dalam mewujudkan visi dan misi. Akibatnya, mereka harus meningkatkan kinerja pekerja pada tujuan. Penelitian ini menggunakan pendekatan kuantitatif dengan variabel bebas yaitu kepemimpinan, disiplin kerja, motivasi, dan upah. Variabel terikat yang

Economica: Jurnal Ekonomi Islam - Volume 12, Nomor 1 (2021) 
Heni Noviarita, Roslee bin Ahmad, and Idzam Fautau

digunakan dalam penelitian ini adalah kinerja karyawan. Hasil penelitian menunjukkan bahwa kepemimpinan, disiplin kerja, motivasi, dan upah berpengaruh signifikan terhadap karyawan perusahaan. Hal ini terlihat dari besarnya thitung sebesar 45,804 > t tabel sebesar 2,51 dengan signifikansi (sig) sebesar $0,000<0,05$. Sekaligus kritis dalam kepemimpinan menyeluruh memberikan upah yang lebih tinggi dan penghargaan mendorong motivasi pekerja, disiplin untuk meningkatkan kinerja pekerja. Sehingga variabelvariabel tersebut dapat meningkatkan kinerja pegawai untuk berprestasi secara bersama-sama di Bank BRI Syariah Cabang Tugumulyo, Bandar Lampung, Sumatera Selatan. Kesimpulannya menyatakan bahwa variabel independen berpengaruh terhadap perusahaan pekerja. Oleh karena itu, sebagai hasilnya, model ini sangat cocok untuk meningkatkan pekerja bank untuk mencapai tujuan mereka.

Kata Kunci: Kepemimpinan; Motivasi; Disiplin Kerja; Upah; Kinerja 
The impact of Leadership, Motivation, Discipline, and Wages on ...

\section{Introduction}

The growth of banks in Indonesia has undergone many changes. Apart from being caused by external factors, bank growth cannot be separated from the internal influence of the bank concerned, such as the development of facilities and services. This rapid development needs to be followed by good human resource management. Human resource management is planning, organizing, implementing, and supervising the procurement, development, provision of remuneration, integration, maintenance, and separation of labor to achieve organizational goals.

Islamic Banks can compete in a competitive industry era that is responsive to their human resources and can direct well-organized human resource performance. As a result, the institution will get many challenges, therefore demanding to improve human resources to make a good performance. Therefore, it is beneficial for the sustainability and progress of the industry (Bernanthos 2018).

The human resource factor (HR) is essential to develop and advance an organization, including a company. Therefore, good HR management in the organization helps realize the company's vision and mission. The right strategy is needed in organizing and managing human resources in a company To improve the quality of human resources (Suherman 2018). The individual performance of its employees strongly influences the success of an organization. Therefore, every company will always strive to improve employee performance in the hope of what the company aims to achieve. Factors that can influence employees' high performance can be triggered by several aspects, such as work motivation.

Human resources are the ultimate resources of an organization. The future and sustainability of the organization depend on knowledge, skills, competencies, and synergy among human resources as the driving force of the

Economica: Jurnal Ekonomi Islam - Volume 12, Nomor 1 (2021) 
organization. Therefore, bank management needs to be encouraged to pay more attention to employee performance.

Performance is the achievement of employees in carrying out their work according to the company plan's targets. Every company is often faced with employee performance problems, so managers always try to carry out every activity effectively and efficiently to achieve maximum results. This requirement is based on the fact that human resources, especially employees, are a significant factor in realizing the company's vision and mission.

Worker's performance affects how many employees contribute to the industry. Each job has specific job criteria or work dimensions that identify the essential elements of a job. Therefore, organizations or companies need to know employees' various weaknesses and strengths to improve weaknesses and strengthen the advantages to improve productivity and employee development. In addition, each agency's workers' performance must be applied to advance the agency (Nasution, Sembiring, and Harahap 2021).

In an organization, the role of the leader is a very influential factor in the achievement of employee performance. It can even be said that the progress achieved or the role of its leader determines setbacks experienced by an organization. Leadership is the ability to influence the activities of other parties, both individually and in groups, through communication to achieve predetermined goals. In addition, leadership is how a leader influences subordinates' behavior to work together productively to achieve organizational goals. That shows that leadership has an essential role in achieving good employee performance. Leaders must apply appropriate leadership according to existing situations and conditions so that employees are expected to work comfortably and with high morale.

The existence of education and high work discipline within the employees of a company will make these employees effective at work. In addition, responsibility, desire, and courage to innovate in the work process in 
the company are manifestations of the existence of high work discipline in employees. As a result, employee performance will continue to improve and have an impact on overall company performance.

As the Central Bank of Malaysia (BNM) requested, all banking industry in Malaysia must constantly train their employees to face many obstacles and challenges (Sija 2021). Thus, it is wise for the banking employer at this time to professionally strategizing planning its workforce. Resulted from the Leadership, motivation, and others affect the performance of subordinates. Therefore, accountable and capable leadership coupled with the ability to foster will produce output from the work of accountable workers (Hudriati et al. 2019).

Performance can only be improved with high work motivation, knowledge and expertise in performing tasks, and a positive perception of one's role. Thus performance is a function of motivation, expertise, and perception. Therefore, there are two essential dimensions in understanding the concept of performance: the dimensions of motivation and the dimensions of ability (skill and perception). In other words, an employee will achieve high performance if he has high motivation in carrying out his duties.

Accountable and competent leadership coupled with fostering ethos and work motivation will produce output or performance from accountable employees' work. The results of work or performance are categorized in two ways. First, the tangible can be seen and counted, and second, the intangible, but an organization can feel the benefits

Al-Qur'an motivates every Muslim to work diligently, as in Sura AtTaubah verse 105, the translation of which is as follows:

And say, "Do [as you will], for Allah will see your deeds, and [so, will] His Messenger and the believers. And you will be returned to the Knower of the unseen and the witnessed, and He will inform you of what you used to do." 
Heni Noviarita, Roslee bin Ahmad, and Idzam Fautau

Wages are used to motivating employees to improve their work performance and stimulate employees to play an active role in achieving company goals. In addition, wages are one of the factors that affect employee performance.

\section{Literature review}

\section{Performance}

Organizational citizenship behavior (OCB) is characterized by voluntary initiatives, namely prosocial contributions to the organization and colleagues. Working above formal jobs and outside formal jobs roles is increasingly crucial in the organizational context. OCB is a behavior of a discretionary person that is not explicitly recognized because of a formal reward system, and in aggregate, encourages more effective organizational functions (Organ 1988). OCB is employee behavior that aims to increase the effectiveness of company performance without ignoring the productivity goals of individual employees. The employees' existence as an organizational locomotive needs to get management's attention because employees make the organization perform well. Spiritual intelligence and organizational citizenship behavior (OCB) improve employee performance (HM 2018).

Etymologically, performance comes from the word work performance. As stated by Mangkunegara (2005), Kolb, Rubin, and McIntyre (1974), and Sedarmayanti (2004), performance is the result of work both in quality and quantity achieved by an employee in carrying out his duties according to the responsibilities assigned to him. Generally, performance can be divided into two, namely individual performance and organizational performance. Individual performance results from employee work, both in quality and quantity, based on predetermined work standards, while organizational performance is a combination of individual performance and group performance. 
Table 1. Likert scale

\begin{tabular}{cl}
\hline Weight & Category \\
\hline 5 & Strongly agree \\
4 & Agree \\
3 & Disagree less \\
2 & Disagree \\
1 & Strongly Disagree \\
\hline
\end{tabular}

The method of measurement is by conducting interviews with respondents and filling out questionnaires using a Likert scale. With a Likert scale, the variable to be measured is translated into a variable indicator. The indicator is used as a starting point for arranging instrument items in questions or statements. The answer to each instrument that uses the Likert scale has a gradient from very positive to very negative, which can be in the form of words, see Table 1.

Questionnaires are instruments or intermediary tools in the form of research questions addressed to respondents. The questionnaire used is a closed questionnaire, where the respondent chooses the answer that has been provided. The questionnaire is an efficient data collection technique if the researcher knows exactly what variables to measure and what can be expected from the respondent.

\section{Leadership}

Leadership is one of the factors to develop an employee's performance. Indeed, leadership is the behavior of a leader in supporting, affecting the morale of subordinates. Generally, each leader always expects their subordinates to have the capability and willingness to carry out and complete the chore at hand correctly (Sumaryo et al. 2015). Furthermore, the process also requires proper supervision to minimize or correct errors by the leader to achieve the goals. Thus, leadership serves as a tool to guide, lead, build, 
Heni Noviarita, Roslee bin Ahmad, and Idzam Fautau

motivate work, move the organization, build communication networks, provide efficient supervision, and bring followers to the target.

Sahih Bukhari from Ibnu Umar RA No. 893 stated, "Every one of you is a leader and will be held accountable for your leadership." Various leadership theories put forward by leadership teachers are found in the person and leadership of Prophet Muhammad. Islamic Spiritual Capital is a set of beliefs, role models (leadership), motivation, ethos, and commitment embodied in virtue values guided by the Qur'an and Hadith of the Prophet Muhammad as well as being a basic foundation in human relations with the creator of Allah (hablumminallah) and human relations with each other (hablumminannas), as well as how to instill these virtue values in their lives and work.

According to Dubrin, Dalglish, and Miller (2006); Siagian (2002); KiecoltGlaser et al. (2005); and Hofstede, Hofstede, and Minkov (2010) Leadership greatly affects the performance of employees because leadership is a way that someone has in influencing a group of people or subordinates to work together and make full efforts passion and confidence to achieve the goals that have been set. Davis and Newstrom (1995), Robbins (2003) explains that leadership plays an essential role in organizational success, especially seen in the performance of its employees. What can be seen is how a leader can influence his subordinates to produce effective and efficient work.

Based on Sutrisno (2016) description, it can be concluded that a leader must have several characteristics, including (1) having sufficient knowledge and abilities to control the company, (2) has more privileges, (3) understands the habits of the person for whom they are responsible, (4) has charisma and dignity, (5) is consistent with truth, (6) is gentle and compassionate, (7) likes an atmosphere of mutual forgiveness, deliberate, put all matters in order, and make up one's mind, (8) build awareness of the supervision of Allah SWT, (9) provide social assistance to members, (10) have an influence that can govern and prevent damage to the earth, and (11) willing to listen to advice and not being arrogant. 
The method of measurement is by conducting interviews with respondents and filling out questionnaires using a Likert scale. With the Likert scale, the variables to be measured are translated into variable indicators. Then these indicators are used as a starting point for compiling instrument items which can be questions or statements. Anket is an instrument or intermediary tool in the form of questions from researchers who are usually addressed to respondents to be answered. The questionnaire used was a closed questionnaire, where the respondent only had to choose the answers provided. The questionnaire is an efficient data collection technique if the researcher knows exactly what variables to measure and what can be expected from the respondent.

\section{Work discipline}

Work discipline is the attitude of a person's willingness and willingness to comply with and obey the various regulatory norms that apply around him. Both the individual and the organization need discipline. Discipline shows a condition or attitude that exists in employees towards company rules and regulations. Thus, employees have poor work discipline if the existing rules or regulations are ignored or frequently violated. Conversely, if employees are subject to company regulations, it represents a condition of good discipline. Discipline means actions taken with supervision to correct wrong behavior and attitudes in employees.

Discipline is beneficial in a work environment, especially for a leader who wants to set an example for his employees. Discipline can improve the quality of character seen in one's commitment to Allah SWT, the organization, oneself, others, and work. The peak of commitment will be seen in high and resilient self-integrity. This kind of attitude can support improving the quality of character, attitude, and work. The quality of attitude, namely commitment and integrity, needs to be supported, developed and manifested in reality. Commitment and integrity will be seen as an inconsistent performance.

Economica: Jurnal Ekonomi Islam - Volume 12, Nomor 1 (2021) 
Heni Noviarita, Roslee bin Ahmad, and Idzam Fautau

The motivation of working is the driving power that resulted in the person's institution agents want and willing to move his ability in the form of capabilities and power to manage various activities. It is an obligation within the framework of the goal, the objectives, and the targets of the various industries defined. The Indicators of work motivation are the driving power, willpower, willingness, expertise, skills, responsibilities, obligations, and others (Rivaldo and Ratnasari 2020).

Companies whose business activities are related to origin resources must be socially and environmentally responsible for many aspects of resources, such as employers and others. Social and environmental responsibility is the company's commitment to participate in sustainable effectiveness development of its company in order to improve the quality of life and the environment that is beneficial, both for the company itself, the local community, and society in general (Rizki, Agriyanto, and Farida 2019). The value of the company is reflected in the strength of the bargaining stock. If the company is estimated as a company with good prospects in the future, the value of the stock will be high. Conversely, if the company is considered to have fewer prospects, then the stock price becomes weak (Ferina and Tjandrakirana DP 2015).

Discipline is obedience to respect and implement a system that requires people to submit to the decisions, orders, and regulations in force. In Islamic teachings, there are many verses of the Quran and hadith that command discipline in the sense of obedience to predetermined regulations, including in the Qur'an, Surat An-Nisa verse 59, which translates as follows:

O you who have believed, obey Allah and obey the Messenger and those in authority among you. And if you disagree over anything, refer it to Allah and the Messenger, if you should believe in Allah and the Last Day. That is the best [way] and best in result. 
The hadith is narrated: "a Muslim must listen to and obey the leader for something he likes or hates unless he orders the immoral." The standard of obedience and disobedience to the leader is that there is no obedience if the order is immoral or contradicts sharia values. If a leader's decree is out of the sharia provisions, his subordinates do not have to implement it. Every Muslim person must be aware of his responsibilities and know the level of his obedience. Their obedience is not blind obedience to the leader to follow him in immorality and prohibited things so that he will lose the world and the hereafter.

The method of measurement is by conducting interviews with respondents and filling out questionnaires using a Likert scale. With the Likert scale, the variables to be measured are translated into variable indicators. Then these indicators are used as a starting point for compiling instrument items which can be questions or statements. Anket is an instrument or intermediary tool in the form of questions from researchers who are usually addressed to respondents to be answered. The questionnaire used was a closed questionnaire, where the respondent only had to choose the answers provided. The questionnaire is an efficient data collection technique if the researcher knows exactly what variables to measure and what can be expected from the respondent.

\section{Motivation}

Motivation is a process that explains a person's strength, direction, persistence to achieve goals (Robbins and Judge 2015). Job satisfaction, motivation, and reward systems are widely discussed in theory put forward by Maslow (1954), Johnson and McClelland (1984), Herzberg (1976), and McGregor (1960). The drivers that result in an organization member willing and willing to deploy abilities in the form of skills, expertise, energy, and time to carry out various activities that are their responsibility and fulfill their 
Heni Noviarita, Roslee bin Ahmad, and Idzam Fautau

obligations to achieve the goals and objectives of the organization that have been determined.

The motivation of working is a process that shows individual intensity, direction, and perseverance of effort towards achieving the objectives. Motivation is the responsibility towards by the employees, employers, and colleagues. The need for achievement, good work, and grit will ensure honesty in work and tenacity or concerns if faced with failure. Performance is the output generated by an occupation or profession's functions or indicators within a specified time. In addition, the meaning of work ethic is a work spirit based on specific values or rules. Because of, Work ethic can also be interpreted as a human attitude or view of the work done and based on the values he believes. So those values can come from a specific religion, customs, culture, and certain laws and regulations that apply in a country (Huda 2016).

Seeking lawful sustenance in Islam is obligatory. This indicates how important it is to seek halal sustenance. Thus, work motivation in Islam is fulfilling a living and an obligation of other religious worship. Therefore, Islam is worthy of being chosen as a way of life (way of life). Islam does not only talk about moral morality but also provides a foundation for the concept of building a life and high civilization.

Islam encourages people to choose activities and careers that are in line with their tendencies and talents. Thus, Islam lays a solid foundation for freedom of business. It is just that, in order to avoid various symptoms of crime, Islam places various boundaries. This goal is stated in the Qur'an by the expression that work is worship because many people's motivations work for material pursuits for the sake of worldly interests; at the very least, they do not care about the interests of the hereafter.

The method of measurement is by conducting interviews with respondents and filling out questionnaires using a Likert scale. With the Likert scale, the variables to be measured are translated into variable indicators. 
These indicators are used as a starting point for compiling instrument items which can be questions or statements. Anket is an instrument or intermediary tool in the form of questions from researchers who are usually addressed to respondents to be answered. The questionnaire used was a closed questionnaire, where the respondent only had to choose the answers provided. The questionnaire is an efficient data collection technique if the researcher knows exactly what variables to measure and what can be expected from the respondent.

Organizational citizenship behavior was initially conceptualized as extrarole behavior valued by the organization but in the formal reward system not explicitly recognized, and leader-member exchange. This is a model offered for the effectiveness of the functions of new forms of organization. Katz identifies three employee behaviors essential for the organization's effectiveness: entering and staying in the organization as employees, performing memorable roles as needed, and being bound to innovative and spontaneity or unplanned activities outside the role performed (HM 2018).

\section{Wage}

The Government has regulated the employment policies, especially regarding the handling of wages called regional minimum wage. However, concerning the need for a regional minimum wage for workers, it will not be separated from wages (Hartono 2018).

Wages are rights that workers must receive as a form of compensation for their work based on an agreement, and the scope includes the welfare of their families. Another case in government regulations defines wages as compensation from employers to workers for work/services that have been or will be performed. Wages are stated in the form of money which is determined based on the work agreement between the entrepreneur and the worker.

Economica: Jurnal Ekonomi Islam - Volume 12, Nomor 1 (2021) 
The Islamic concept as taught in the Qur'an discusses wages in general. However, it does not mean that the concept of wages is not regulated in the concept of sharia. The discussion is summarized in a philosophical form that still requires its interpretation. The discussion of wages in Islam is categorized as the concept of ijarah, while ijarah itself tends to discuss the issue of renting. Therefore, there is relatively little discussion of wages in Islam, even if there are all of them only as values or norms.

Wages are given based on the level of need and welfare rates for the local community. During the time of the Caliph Umar, employees' salary was adjusted to the local community's level of needs and welfare. The wages given to workers can sometimes be paid in kind, not in cash. The wage system in wages needs to be given based on the employee's work performance. This wage system provides many opportunities for organizations or companies to progressively develop for young employees who are sufficiently aged and supported by the expected competencies. This kind of wage system uses the basis of calculating employees' work performance to determine the size and size of the wages that can be given.

The method of measurement is by conducting interviews with respondents and filling out questionnaires using a Likert scale. With the Likert scale, the variables to be measured are translated into variable indicators. Then these indicators are used as a starting point for compiling instrument items which can be questions or statements. Anket is an instrument or intermediary tool in the form of questions from researchers who are usually addressed to respondents to be answered. The questionnaire used was a closed questionnaire, where the respondent only had to choose the answers provided. The questionnaire is an efficient data collection technique if the researcher knows exactly what variables to measure and what can be expected from the respondent. 
The impact of Leadership, Motivation, Discipline, and Wages on ...

\section{Methods}

This type of research is field research, which is research conducted in the real world. Field research is research carried out in a particular community, including at various government agencies.

This research uses a quantitative approach. Quantitative research can be interpreted as a research method based on the positivist philosophy of examining populations based on a particular sample. Data collection uses research instruments; data analysis is quantitative/statistical to test predetermined hypotheses. The population of this study is all employees. There are 100 employees who work at BRIS Bandar Lampung Branch and BRIS Tugumulyo Branch, South Sumatra. Therefore, all of these employees were used as research samples, namely 100 respondents using the accident sampling method.

The data obtained must be tested for validity and reliability before the statistical test is carried out to get research results. The validity and reliability tests are used to measure the questions to avoid deviating and being accurate. This study is valid if it can measure what is being measured from the variables studied. Validity measurement is done using the Pearson product-moment formula and a significant level of 0.05 or $5 \%$.

The validity test should be done on each question item in the validity test carried out with the help of SPSS 22. We compare the results of $r$ count with the $r$ table where $\mathrm{df}=\mathrm{n}-2$ with a significance of 0.05 or $5 \%$. If $r$ table $<\mathrm{r}$ count then valid. In testing the validity of the instrument in this study, item analysis was used. The method of measuring the item analysis is to correlate the item score with the total score with the comment product formula, namely:

$$
R x y=\frac{N \sum x y-\left(\sum x\right)\left(\sum y\right)}{\sqrt{\left\{N \sum x^{2}-\left(\sum x^{2}\right)\right\}\left\{y^{2}-\left(\sum x^{2}\right)\right\}}}
$$

Economica: Jurnal Ekonomi Islam - Volume 12, Nomor 1 (2021) https://journal.walisongo.ac.id/index.php/economica 
Heni Noviarita, Roslee bin Ahmad, and Idzam Fautau

Information :

$\mathrm{R}=$ correlation coefficient

$\mathrm{N}=$ Number of subjects or respondents

$\mathrm{X}=$ Item score

$\mathrm{Y}=$ total score

Reliability shows that an instrument can be trusted enough to be used as a data collection tool because the instrument is good. In addition, reliability shows the extent to which an instrument can produce results. Consistent measurement is when repeated measurements are made of the same symptoms with the same measuring instrument.

Reliability tests were carried out on data that were declared valid. Performed using the Cronbach alpha technique $>0.60$. The Cronbach alpha formula is as follows:

$$
r_{11}=\left[\frac{K}{K-1}\right]\left[1 \frac{\sum \sigma_{b}^{2}}{\sigma_{1}^{2}}\right]
$$

Information :

K : Number of Questionnaires

$\mathrm{R}$ : Reality of the Instrument

$\sum \sigma:$ Number of grain variants

$\sigma$ : Total Variant

\section{Result and discussion}

\section{T-test}

The t-test is used to determine the significance of the effect of the independent variable partially on the dependent variable. If tcount $<t_{\text {table }}$ then $\mathrm{H} 0$ is accepted, meaning that variable $\mathrm{X}$ has no effect on variable $\mathrm{Y}$, and vice versa if tcount $>$ ttable, then $\mathrm{H} 0$ is rejected, meaning that variable $\mathrm{X}$ affects variable Y.The tcount value can be obtained from the formula $\mathrm{df}=\mathrm{n}-\mathrm{k}-1$ or $\mathrm{df}$ 
$=70-4-1=65$, so that the $t$ table value is 1.997 . The test criterion is if the significance value $<0.05$ and tcount $>$ ttable then $\mathrm{H} 0$ is rejected, it means there is an influence; on the contrary, if the significance value $>0.05$ and tcount $<$ ttable then $\mathrm{HO}$ is accepted, then there is no effect. The results of hypothesis testing for each variable are as table 2 .

Based on Table 2, It is known that the t value for the leadership variable (X1) is 2.738 , the t table is 1.997 , and the significance is 0.008 . Therefore tcount $>$ ttable and significance $<0.05$ then Had is accepted. This means that leadership (X1) partially affects employee performance (Y). The value of $t$ for the motivation variable (X2) is 6.431, while the $t$ table is 1.997 , and the significance is 0.00 . Therefore tcount $>$ ttable and significance $<0.05$, then Ha is accepted. This is significant; partially motivated (X2) affects employee performance $(\mathrm{Y})$. The $\mathrm{t}$-count for the discipline variable $(\mathrm{X} 3)$ is 3,413 , the $\mathrm{t}$ table is 1.997, and the significance is 0.001 . Because count $>t$ table and significance $<0.05$, Ha is accepted. This means that work discipline (X3) partially affects employee performance (Y). It is known that the value of $t$ for wages (X4) is 2.552 , $\mathrm{t}$ table is 1.997 , and the significance is 0.013 because tcount $>$ ttable and significance $<0.05$, Ha is accepted, meaning that wages (X4) partially affect employee performance (Y).

Table 2. Significance Test (Ujit)

\begin{tabular}{|c|c|c|c|c|c|c|}
\hline \multicolumn{7}{|c|}{ Coefficientsa } \\
\hline \multirow{2}{*}{\multicolumn{2}{|c|}{ Model }} & \multicolumn{2}{|c|}{$\begin{array}{l}\text { Unstandardized } \\
\text { Coefficients }\end{array}$} & \multirow{2}{*}{$\begin{array}{l}\text { Standardized } \\
\text { Coefficients } \\
\text { Beta }\end{array}$} & \multirow[t]{2}{*}{$T$} & \multirow[t]{2}{*}{ Sig. } \\
\hline & & B & Std. Error & & & \\
\hline \multirow[t]{5}{*}{1} & (Constant) & 7,849 & 4,374 & & 1,794 & 0.077 \\
\hline & Leadership & 0.840 & 0.307 & 0.292 & 2,738 & 0.008 \\
\hline & Motivation & 1,530 & 0.238 & 0.589 & 6,431 & 0,000 \\
\hline & Discipline of Work & 1,179 & 0.345 & 0.400 & 3,413 & 0.001 \\
\hline & Wage & 0.912 & 0.357 & 0.320 & 2,552 & 0.013 \\
\hline
\end{tabular}

Economica: Jurnal Ekonomi Islam - Volume 12, Nomor 1 (2021) 
Heni Noviarita, Roslee bin Ahmad, and Idzam Fautau

Table 3. Significance Results (F Test)

\begin{tabular}{lrrrrrr}
\multicolumn{8}{c}{ ANOVAa } \\
\hline Model & $\begin{array}{r}\text { Sum of } \\
\text { Squares }\end{array}$ & df & $\begin{array}{r}\text { Mean } \\
\text { Square }\end{array}$ & F & Sig. \\
& 1084,886 & 4 & 271,221 & 45,804 & $0,000 \mathrm{~b}$ \\
\hline $1 \quad$ Regression & 384,886 & 65 & 5,921 & & \\
& Residual & 1469,771 & 69 & & & \\
& Total & &
\end{tabular}

aDependent Variable: Performance

bPredictors: (Constant), Leadership, Motivation, Discipline, Wages

Source: Processed from primary data (2019)

\section{F test}

The $\mathrm{F}$ test is carried out to know how far the independent variables influence the dependent variable together. Table 3 shows that the Fcount value is 45.804 , the Ftable value is 2.51 , and the significance is $0.000<0.05$. This means there is an influence between leadership (X1), motivation (X2), discipline (X3), wages (X4), and employee performance (Y). The coefficient of determination $\left(\mathrm{R}^{2}\right)$ measures how far the model can explain variations in the dependent variable. The coefficient of determination is between zero and one. Small $\mathrm{R}^{2}$ means that the ability of the independent variables to explain the variation in the dependent variable is minimal. A value close to one means that the independent variable provides a value for all the information needed to predict the variation of the independent variable. In general, the determinant coefficient for cross-section data is relatively low due to the considerable variation between each observation.

Table 4. Determination Coefficient Test Results (R2)

Model Summary

\begin{tabular}{lllll}
\hline Model & $\boldsymbol{R}$ & $\boldsymbol{R}$ Square & $\begin{array}{l}\text { Adjusted } \mathbf{R} \\
\text { Square }\end{array}$ & $\begin{array}{l}\text { Std. Error of the } \\
\text { Estimate }\end{array}$ \\
\hline 1 & $0.859 \mathrm{a}$ & 0.738 & 0.722 & 2,433 \\
\hline
\end{tabular}

a Predictors: (Constant), Wages, Motivation, Leadership, Discipline

Source: Processed from primary data (2019) 
According to Table 4, R2 value is 0.738 or $73.8 \%$. This shows that the percentage of the influence of leadership, motivation, work discipline, and wages on the performance of the employees of BRIS Bandar Lampung Branch and BRIS Tugumulyo Branch, South Sumatra is 73.8\%. In other words, employee performance variables can be explained or influenced by leadership, motivation, discipline, and wages as much as $73.8 \%$. In comparison, the remaining $26.2 \%$ is explained or influenced by other variables not examined.

Multiple regression is used for one dependent variable and more than one independent variable. Although multiple regression is more widely used in business practice, there are many variables in the business that need to be analyzed together. Besides that, in many cases, multiple regression is more relevant.

Based on Table 5, the multiple linear regression equation formed for this study is as follows:

$$
Y=7,849+0,840 X_{1}+1,530 X_{2}+1,179 X_{3}+0,912 X_{4}
$$

Table 5. Multiple Regression Test

\begin{tabular}{|c|c|c|c|c|c|c|}
\hline \multicolumn{7}{|c|}{ Coefficientsa } \\
\hline \multirow{2}{*}{\multicolumn{2}{|c|}{ Model }} & \multicolumn{2}{|c|}{$\begin{array}{l}\text { Unstandardized } \\
\text { Coefficients }\end{array}$} & \multirow{2}{*}{$\begin{array}{l}\text { Standardized } \\
\text { Coefficients } \\
\text { Beta }\end{array}$} & \multirow[t]{2}{*}{$t$} & \multirow[t]{2}{*}{ Sig. } \\
\hline & & B & Std. Error & & & \\
\hline \multirow[t]{5}{*}{1} & (Constant) & 7,849 & 4,374 & & 1,794 & 0.077 \\
\hline & Leadership & 0.840 & 0.307 & 0.292 & 2,738 & 0.008 \\
\hline & Motivation & 1,530 & 0.238 & 0.589 & 6,431 & 0,000 \\
\hline & Work Discipline & 1,179 & 0.345 & 0.400 & 3,413 & 0.001 \\
\hline & Wage & 0.912 & 0.357 & 0.320 & 2,552 & 0.013 \\
\hline
\end{tabular}

a. Dependent Variable: Performance

Source: Processed from primary data (2019)

Economica: Jurnal Ekonomi Islam - Volume 12, Nomor 1 (2021) https://journal.walisongo.ac.id/index.php/economica 
Heni Noviarita, Roslee bin Ahmad, and Idzam Fautau

A constant value of 7.849 means that if the value of leadership, motivation, work discipline, and wages is 0 , employee performance will increase by 7.849. The regression coefficient value on the leadership variable (X1) is positive at 0.840 , meaning that each leadership increase of 1 unit will increase performance. Employees are equal to 0.840 units, assuming the independent variable is fixed in value. The regression coefficient value on the motivation variable $(\mathrm{X} 2)$ is positive at 1.530 . Therefore, increasing motivation by 1 unit will increase employee performance by 1.530 units, assuming the independent variable is fixed. The work discipline variable (X3) is positive, which is 1.179. Therefore, increasing work discipline by 1 unit will increase employee performance by 1,179 units, assuming the independent variable has a fixed value. The regression coefficient value on the wage variable (X4) is positive, 0.912 , meaning that every 1 unit increase in wages will increase employee performance by 0.912 units, assuming the independent variable has a fixed value.

\section{The influence of leadership on employee performance}

Leadership is an effort to influence many people through communication to achieve goals, with directions or orders, actions that cause others to act or respond and cause positive change. Dynamic strength is essential to motivate and coordinate the organization to achieve goals and create confidence and support among subordinates to achieve organizational goals.

Based on the regression equation results, the regression coefficient for leadership is 0.840 , the $\mathrm{t}$-count value is $2.738>\mathrm{t}$-table 1.997 , and the probability value is $0.008<0.05$ so that $\mathrm{Ha}$ is accepted. Therefore, leadership significantly affects employee performance at BRIS Bandar Lampung Branch and BRIS Tugumulyo Branch, South Sumatra. Therefore, in this study, it is known, if there is an increase in leadership by $1 \%$, it will increase employee performance by $0.840 \%$. 
In this way, it can be said that the results of the implementation of managerial leadership activities that are carried out have a positive or good impact on the company because the better the implementation of managerial leadership activities is carried out, the impact on increasing the company's performance from time to time. Furthermore, implementing leadership activities that direct employees more can cause an employee to achieve satisfaction at work and can positively influence the subordinates' personality to work sincerely to achieve company goals.

The results showed that the leadership style applied in BRIS Bandar Lampung Branch and BRIS Tugumulyo Branch South Sumatra was democratic. Its leaders were role models in certain human traits, such as gentleness and virtue, and humanity. This is shown by the leaders of BRIS Bandar Lampung Branch and BRIS Tugumulyo Branch, South Sumatra. When making decisions, they always hold deliberations. Hypothesis testing shows that leadership style has a positive and significant effect on employee performance. This finding explains that the more democratic the leadership style is applied, the higher the employee's performance. This leadership style has a happy behavior to accept suggestions, opinions, and criticism from subordinates. This leadership style needs to be maintained,

The results of this study are supported by the theory put forward by Amirullah (2015). Leadership is a person who has the authority to give tasks, can persuade or influence others through a pattern of good relationships in order to achieve predetermined goals. Apart from that, it is also supported by the theory put forward by Kartika (2014), three characteristics of a democratic leadership style are: (1) decisions and policies are made jointly between leaders and subordinates, (2) communication takes place reciprocally, both between leaders and subordinates as well as fellow subordinates and (3) many opportunities for subordinates to convey suggestions, considerations or opinions. In addition, the results of this study also support previous research conducted by Jati (2014), which found that 
Leadership style and job training partially have a positive and significant effect on employee performance.

This research aligns with Dubrin, Dalglish, and Miller (2006) stated that leadership affects many people through communication to achieve goals. The way to influence people is (1) with instructions or orders, actions that cause others to act or respond and cause positive change, (2) strength important dynamics that motivate and coordinate the organization in order to achieve goals, and (3) the ability to create confidence and support among subordinates so that organizational goals can be achieved.

This research is also supported by Brahmasari and Suprayetno's (2008) research, which states that leadership has a positive and significant effect on company performance. In addition, research conducted by Fauzi (2011) revealed that leadership has a positive and significant influence on company performance

According to researchers, leadership is inspiring all employees to work their best to achieve the expected results. In addition, leadership is getting employees to act rightly to achieve commitments and motivate them to achieve common goals.

These findings encourage the statement that the behavior of the leader determines success or failure. This behavior will be seen in giving orders, decisions, assigns, communication, encouraging subordinates, guidance, discipline, chairing meetings, and others. This can mean that a person who has leadership would potentially carry out the task at hand.

\section{The influence of motivation on the employee performance}

Motivation is an essential variable, so organizations need to get significant attention in improving employee performance. Work motivation is the encouragement or enthusiasm that arises in a person or employee to do something or work because of external stimulation from both the boss and the 
work environment, the desire to fulfill needs and feelings of satisfaction and fulfill responsibility for the tasks given and done in the organization.

From the results of the regression equation, the regression coefficient value for work motivation is 1.530 . Besides that, it has a t-count value of 6.431 $>t$-table with a value of 1.997 and a probability value of $0.000<0.05$, so Ha is accepted. This means work motivation significantly affects employee performance at BRIS Bandar Lampung Branch and BRIS Tugumulyo Branch, South Sumatra. That way, if there is an increase in motivation by $1 \%$, it will increase employee performance by $1.530 \%$.

BRIS Bandar Lampung Branch and BRIS Tugumulyo Branch, South Sumatra, always apply various motivations to their employees. For example, show the best behavior and potential to get the job done. In addition, BRIS Bandar Lampung Branch provides rewards that build motivation so that employees will give their best contribution to work, such as arriving on time to finish their work immediately.

The results of Sari, Muis support the research that motivation affects employee performance, meaning that increasing employee motivation can be done by rewarding employees who excel. This study also follows the theory put forward by Hasibuan (2003), which argues that motive is an incentive to desire and a driving force for a person's willingness to work because each motive has a specific goal to be achieved. So it can be concluded that the greater the company motivates employees, the greater its performance. Meanwhile, according to Wexley and Yukl (1984), motivation is a process of providing behavior with energy and direction.

From these two explanations, it is understood that motivation can be interpreted as giving inner impulses so that other parties move/take specific actions. So it can be further concluded that motivation is a series of activities to encourage, namely not only to others but also to oneself. Through this encouragement, it is hoped that they will be able to act towards the desired 
Heni Noviarita, Roslee bin Ahmad, and Idzam Fautau

goal. This is also supported by research conducted by Parlinda and Wahyuddin (2009), which shows that work motivation variables have a positive but insignificant effect on company performance.

This research is in line with Noviarita (2017), which states that motivation (X2) has a significant effect on employee performance (Y). According to researchers, motivation is a person's tendency to engage in activities that lead to goals. For example, suppose the behavior leads to an object/target, then with the motivation of achieving the maximum possible target or target.

Based on the analysis above, it can be concluded that motivating employees can be done in various ways, namely positive motivation such as gifts, bonuses, and awards and promotions. However, it is also in the form of negative motivation, such as giving punishments for employees who make mistakes, sanctions against employees who violate the rules, and sanctions being fired if they are proven to have made a fatal mistake. Due to this, motivation significantly influenced the performance of the employee. Besides those factors, the company should apply better maintenance for the work environment to increase the employees' performance.

\section{The effect of work discipline on the employee performance}

From the regression equation results, the regression coefficient value for work discipline is 1.179, the value of tcount $3.413>t$ table 1.997, and a probability value of $0.001<0.05$ so that Ha is accepted. This means that work discipline significantly affects the BRIS Bandar Lampung Branch and BRIS Tugumulyo Branch, South Sumatra. Furthermore, if there is an increase in work discipline by $1 \%$, it will increase employee performance by $1.179 \%$. This finding is supported by the results of previous research, which states that work discipline, partially, has a positive effect on employee performance.

One of the factors that affect employee performance is work discipline. According to Simamora (2004), discipline is a procedure that corrects or 
punishes subordinates for violating rules or procedures. Work discipline is a tool used by managers to communicate with employees so that they are willing to change behavior and as an effort to increase one's awareness and willingness to obey all applicable company regulations and social norms.

Work discipline is influenced by employee morale, the level of compensation given, and employee job satisfaction. Employees with high morale tend to do better, on time, and never skip class. Employees will be enthusiastic about going to work so that their work discipline becomes high. Based on the various aspects above, work discipline will have a significant effect on company performance. When the level of work discipline of a company is high, it is expected that the employees will work better to increase their productivity. In addition, good work discipline will increase work efficiency as much as possible. Do not spend much time for the company to improve the disciplinary aspects, and time can be used to achieve company goals.

The effect of work discipline on employee performance has been suggested in (Ariana and Riana 2013). This study indicates that companies can pay more attention to employee abilities, remuneration for employees, sanctions for disciplinary violations, and tighter supervision to improve or improve employee performance. These various things prove that work discipline is an essential factor in improving employee performance.

With reasonable work discipline from employees such as arriving on time, carrying out work following what has been set by the company, obeying company regulations, it will be able to improve the performance of these employees so that the company's targets will be achieved.

This research is in line with research conducted by Ariana and Riana (2013). They researched the influence of leadership, compensation, and work discipline on employee performance at Hotel Cendana Resort and Spa Ubud 
Heni Noviarita, Roslee bin Ahmad, and Idzam Fautau

Gianyar Bali. The results of this study indicate that work discipline variables affect employee performance.

Based on the results of this study, discipline is the main thing in life, both in the world of work and others. Employee discipline is needed so that the activities carried out run according to expectations. With discipline, employees will not take various actions that are detrimental to the company.

\section{The effect of wages on the employee performance}

Based on the regression equation results, the regression coefficient for wages is 0.912 , the $\mathrm{t}$-count value is $2.552>\mathrm{t}$-table 1.997 , and the probability value is $0.013<0.05$ so that Ha is accepted. This means that wages significantly affect employee performance at BRIS Bandar Lampung Branch and BRIS Tugumulyo Branch, South Sumatra. Thus, if there is an increase in wages of $1 \%$, it will increase employee performance by $0.912 \%$.

Acceptance of the hypothesis follows the opinion of Umar (2004), which states that wages are remuneration for the implementation of work and motivating employees. The primary purpose of paying wages is to retain the employees of the organization in the long term. The company gives Wages to employees to increase welfare because one fundamental aspect of someone working or being an employee at a company is to earn income for their living expenses. By providing a decent salary, employees felt cared for and appreciated for their hard work. In this condition, employees will work with discipline, and the result is higher performance.

This is following the wage system applied by BRIS Bandar Lampung Branch and BRIS Tugumulyo South Sumatra Branch, which provides basic wages to all BRIS employees according to the level of each job wages are given according to a predetermined time. In addition to the basic wage, BRIS Bandar Lampung Branch and BRIS Tugumulyo South Sumatra Branch also provide allowances and bonuses to employees who have good work performance. 
With the provision of allowances and bonuses, employees are competing to produce more effective performance.

The purpose of providing wages by companies is to protect employees and their families from meeting the minimum life needs. In addition, wages are also a form of appreciation to employees who have contributed their energy and thoughts. The amount of reward depends on the level of one's sacrifice (energy and mind). The higher the sacrifice, the higher the income given. This will spur employees to work harder to earn a higher income.

In addition, the determination of wages based on the Regional Minimum Wage, the Government stipulates the Regulation of the Minister of Manpower of the Republic of Indonesia PER-17/MEN/VIII/2005 concerning the Components and Implementation of the Stages of Achieving the Regional Minimum Wage. Moreover, as a rule in the implementation of Article 89 paragraph (4) of Law Number 13 of 2003 concerning Manpower which reads: Components and implementation of stages of achieving decent living needs are regulated by a Ministerial Regulation.

Various attempts are made by a manager to attract, maintain, and pay attention to employees to remain in the company. Companies must provide compensation for services that workers have issued to the company. This reward includes direct financial payments in wages, overtime pay, incentives, commissions, bonuses, and welfare. Providing direct remuneration to employees can be money intended to increase employee productivity and pay attention to outstanding employees at the company. By giving wages, it is hoped that a workforce can be more productive and have complete responsibility for their duties so that its production volume target can be met.

According to researchers, a person works expecting a reward following the type of work. Because given a fair wage, there will be enthusiasm. Workers can meet the necessities of life for themselves and their families, feel needed 
Heni Noviarita, Roslee bin Ahmad, and Idzam Fautau

by the company, and need the work to have a harmonious reciprocal relationship. This has a positive impact on improving employee performance.

\section{The influence of leadership, motivation, and work discipline on employee performance}

Employee performance cannot be separated from leadership, motivation, work discipline, and the wages given. As previously described, leadership, motivation, work discipline, and wages are essential to achieve maximum employee performance. Therefore, if the four elements are applied together, the employee's performance will be maximized.

Based on the regression analysis results, it can be seen that the independent variables have a significant effect on the dependent variable. This is evidenced by the value of Fcount $45.804>$ Ftable 2.51 and a significance of $0.000<0.05$. Therefore, the regression model can be used to predict the performance of BRIS Bandar Lampung employees. Furthermore, the results also show that leadership, motivation, work discipline, and wages simultaneously affect performance.

The $\mathrm{R} 2$ test shows a result of 0.738 or $73.8 \%$. This shows that the percentage of leadership, motivation, work discipline, and wages on the performance of BRISBandar Lampung employees and BRIS Tugumulyo South Sumatra employees is $73.8 \%$. In other words, employee performance variables can be explained or influenced by the variables of leadership, motivation, work discipline, and wages by $73.8 \%$. In comparison, the remaining $26.2 \%$ is explained or influenced by other variables that are not studied, such as work environment conditions, work ethics, and others.

This research is reinforced by research conducted by Noviarita (2017), which states that leadership (X1), motivation (X2), work discipline (X3), wages (X4) are $77.6 \%$ affecting employee performance, while the remaining $22,4 \%$ is influenced by other factors not examined, such as work environment conditions, work ethics, and others. 
Workers Performance can be made by increasing the leadership and motivation and others. Considering divided into two, namely the motivation of the person (intrinsic motivation) and motivation that comes from outside the person (extrinsic motivation), the increased motivation can be finished by increasing the intrinsic motivation and extrinsic motivation boost. Furthermore, improving the motivation can be done by making cooperation among legislators. This can be made through mutual respect, mutual understanding, exchanging the opportunity for advanced positions in a good way.

Based on the research results described above, it appears that leadership, motivation, work discipline, and wages together positively influence employee performance. Thus, to improve the BRIS Bandar Lampung Branch and BRIS Tugumulyo Branch of South Sumatra, they must be given a leadership style, motivation, work discipline, and wages together with that employee performance increase. As a result, leadership, Motivation, and Work Discipline, and wages are parameters that significantly affect the performance of employees in those banks, which is shown by a positive influence among leadership, leadership, Motivation, and Work Discipline and wages on performance. So they are needed to take this matter seriously. The management on those banks always needs to run the leadership, Motivation, and Work Discipline and wages that can increase the innovation and aggressiveness of employees. Therefore, it can positively impact the active increase in the work environment that can certainly affect the performance.

\section{Conclusion}

Based on the background and the formulation of the problems raised in this study, it can be concluded that Leadership, motivation, and work discipline significantly influence employee performance at Islamic banks. This means that employee performance can be explained or influenced by the variables of leadership, motivation, work discipline, and wages statistically by

Economica: Jurnal Ekonomi Islam - Volume 12, Nomor 1 (2021) 
Heni Noviarita, Roslee bin Ahmad, and Idzam Fautau

$73.8 \%$. In comparison, the remaining $26.2 \%$ is explained or influenced by other variables not studied, such as work environment conditions, work ethics, and others. In addition, these variables also support the notion that the factors of knowledge, skills, and length of service affect the performance of individuals. Motivating employees can be done in various ways, namely positive motivation such as gifts, bonuses, and awards and promotions. However, it is also in the form of negative motivation, such as giving punishments for employees who make mistakes, sanctions against employees who violate the rules, and sanctions being fired if they are proven to have made a fatal mistake.

As a result, the leadership and others on those banks are expected to implement a leadership motivation, work discipline, and wage style that is appropriated to the employees' situation and condition. The rewards should be reviewed and enhanced periodically, applying compensation and penalties related to the discipline of work. As a result, the employees will do their performance well. This research is expected to be a consideration in decisions related to the leadership style of work discipline, motivation, and wage affected to the performance of employees.

\section{References}

Amirullah. 2015. Pengantar Manajemen : Fungsi-Proses-Pengendalian. Jakarta: Mitra Wacana Media.

Ariana, I Wayan Tresna, and I Gede Riana. 2013. "Pengaruh Kepemimpinan, Kompensasi Dan Displin Kerja Terhadap Kinerja Karyawan Pada Hotel Cendana Resort \& Spa Ubud, Gianyar." E-Jurnal Manajemen 2 (1): 12136. https://ojs.unud.ac.id/index.php/Manajemen/article/view/4220.

Bernanthos, Bambang. 2018. "Employees' Performance in Islamic Banking." European Research Studies Journal XXI (Issue 1): 31-42. https://doi.org/10.35808/ersj/927.

Davis, Keith, and John W. Newstrom. 1995. Perilaku Dalam Organisasi. Edited by Agus Dharma. Jakarta: Erlangga. 
Dubrin, Andrew J, Carol Dalglish, and Peter Miller. 2006. Leadership, 2nd AsiaPacific Ed. Leadership, 2nd Asia-Pacific Ed. Milton, QLD, Australia: John Wiley \& Sons Australia.

Fauzi, Imam. 2011. “Pengaruh Kepemimpinan Dan Motivasi Terhadap Kinerja Karyawan Pada Unit SKT Brak BL 53 PT. Djarum Kudus." Universitas Negeri Semarang.

Ferina, Ika Sasti, and Rina Tjandrakirana DP. 2015. "Pengaruh Kebijakan Dividen, Kebijakan Hutang, Dan Profitabilitas Terhadap Nilai Perusahaan." Jurnal Akuntanika 2 (1): 52-66.

Hartono, Nono. 2018. "Analisis Ekonomi Islam Terhadap Pemenuhan Upah Layak Tenaga Kerja Industri Batik (Studi Kasus: Sentra Batik Kecamatan Plered Kabupaten Cirebon)." Economica: Jurnal Ekonomi Islam 9 (2): 233-62. https://doi.org/10.21580/economica.2018.9.2.2835.

Herzberg, Frederick. 1976. The Managerial Choice, To Be Efficient and to Be Human. Homewood: Dow Jones-Irwin.

HM, Muhdar. 2018. "The Effects of Spiritual Intelligence and Organizational Citizenship Behavior to Employees Performance: Study at Sharia Banks in Gorontalo Province." Economica: Jurnal Ekonomi Islam 9 (2): 179-205. https://doi.org/10.21580/economica.2018.9.2.2806.

Hofstede, Geert, Gert Van Hofstede, and Michael Minkov. 2010. Cultures and Organizations: Software of the Mind. New York: McGraw-Hill Education.

Huda, Choirul. 2016. "Etos Kerja Pengusaha Muslim (Studi Kasus Pada Pengusaha Muslim Alumni Uin Walisongo Semarang)." Economica:Jurnal $\begin{array}{lllll}\text { Ekonomi } & \text { Islam } & 7 & \text { (2): } & 79-107 .\end{array}$ https://doi.org/10.21580/economica.2016.7.2.1156.

Hudriati, Andi, Rusdiah Rusdiah, Muli Umiaty Noer, and Muhammad Arham. 2019. "EFL Students' Attitude on Mendeley-Based Instruction for Scientific Writing in Indonesian Higher Education." Asian EFL Journal Research Articles 25 (5.2): 79-95. https://www.asian-efljournal.com/wp-content/uploads/AEJ-VOL.25-ISSUE-5.2-OCTOBER2019.pdf.

Jati, Dionysius Dendy Wibowo. 2014. "Pengaruh Gaya Kepemimpinan Dan Pelatihan Kerja Terhadap Kinerja Karyawan: Studi Kasus Pada PT. Sarihusada Generasi Mahardhika." Universitas Sanata Dharma. 
Heni Noviarita, Roslee bin Ahmad, and Idzam Fautau

Johnson, Eric W, and David C McClelland. 1984. Learning to Achieve. Glenview: Scott Foresman and Company.

Kartika, N. 2014. "Definition of Types of Leadership Style and Theory Underlying Leadership. (Location and Name of Publisher)."

Kiecolt-Glaser, Janice K., Timothy J. Loving, Jeffrey R. Stowell, William B. Malarkey, Stanley Lemeshow, Stephanie L. Dickinson, and Ronald Glaser. 2005. "Hostile Marital Interactions, Proinflammatory Cytokine Production, and Wound Healing." Archives of General Psychiatry 62 (12): 1377. https://doi.org/10.1001/archpsyc.62.12.1377.

Kolb, D A, I M Rubin, and J M McIntyre. 1974. Organizational Psychology: A Book of Readings. Behavioral Sciences in Business Series. New York: Prentice-Hall. https://books.google.co.id/books?id=b2APAQAAMAAJ.

Mangkunegara, AP. 2005. "Human Resources Performance Evaluation, Jakarta: Refika Aditama."

Maslow, Abraham H. 1954. Motivation and Personality. New York: Harper and Bros.

McGregor, Douglas. 1960. The Piman Side of Enterprise. New York: McGrawHill.

Nasution, Laili Syafitri, Beby Karina Fawzeea Sembiring, and R Hamdani Harahap. 2021. "Analysis of the Influence of Work Motivation, Locus of Control, and Organizational Commitment to Employee Performance with Islamic Work Ethics as a Moderating Variable (Case Study at Universitas Muhammadiyah Sumatera Utara)." International Journal of Research and Review 8 (1): 615-23. https://www.ijrrjournal.com/IJRR_Vol.8_Issue.1_Jan2021/IJRRAbstract066.html.

Noviarita, Heni. 2017. Pengaruh Motivasi Dan Disiplin Kerja Terhadap Produktivitas Tenaga Kependidikan Di Universitas Islam Negeri Raden Intan Lampung. Lampung: LP2M UIN Raden Intan Lampung.

Organ, Dennis W. 1988. Organizational Citizenship Behavior: The Good Soldier Syndrome. Organizational Citizenship Behavior: The Good Soldier Syndrome. Issues in Organization and Management Series. Lexington, MA, England: Lexington Books/D. C. Heath and Com.

Parlinda, Vera, and M. Wahyuddin. 2009. "Pengaruh Kepemimpinan, Motivasi, Pelatihan, Dan Lingkungan Kerja Terhadap Kinerja Karyawan Pada 
Perusahaan Daerah Air Minum Kota Surakarta." Pascasarjana Universitas Muhammadiyah Surakarta.

Rivaldo, Yandra, and Sri Langgeng Ratnasari. 2020. "Pengaruh Kepemimpinan Dan Motivasi Terhadap Kepuasan Kerja Serta Dampaknya Terhadap Kinerja Karyawan." Jurnal Dimensi 9 (3): 505-15. https://doi.org/10.33373/dms.v9i3.2727.

Rizki, Mita Kurnia, Ratno Agriyanto, and Dessy Noor Farida. 2019. “The Effect of Sustainability Report and Profitability on Company Value: Evidence from Indonesian Sharia Shares." Economica: Jurnal Ekonomi Islam 10 (1): 117. https://doi.org/10.21580/economica.2019.10.1.3747.

Robbins, Stephen P. 2003. Perilaku Organisasi. Jakarta: PT. Indeks Kelompok Gramedia.

Robbins, Stephen P., and Timothy A. Judge. 2015. Organizational Behavior. New Jersey: Pearson Education, Inc.

Sedarmayanti, Sedarmayanti. 2004. Bagian Kedua Membangun Sistem Manejemen Kinerja Guna Meningkatkan Produktivitas Menuju Good Governance (Kepemerintahan Yang Baik). Bandung: Mandar Maju.

Siagian, Sondang P. 2002. Manajemen Sumber Daya Manusia. Jakarta: Bumi Aksara.

Sija, Andrew. 2021. "The Influence Of Job Satisfaction And Its Effect On Employee Turnover Intention In Financial Service Industry Of Malaysia." European Journal of Economic and Financial Research 5 (1). https://doi.org/10.46827/ejefr.v5i1.1066.

Simamora, Henry. 2004. Manajemen Sumber Daya Manusia. Yogyakarta: Bagian Penerbitan STIE YPKN.

Suherman, Usep Deden. 2018. "Pengaruh Penerapan Nilai-Nilai Islami Dan Komitmen Organisasional Terhadap Kinerja Karyawan Pemasaran Bank Umum Syariah Di Jawa Barat." Economica: Jurnal Ekonomi Islam 9 (1): 51-81. https://doi.org/10.21580/economica.2018.9.1.2413.

Sumaryo, Partono, Mansyur Ramly, Ahmad Gani, and Roslina Alam. 2015. "Effects of Job Stress, Leadership on Motivation and Members of Parliament of the Regional House of Representatives Performance." International Journal of Humanities and Social Science Invention 4 (6): 4954. https://www.ijhssi.org/papers/v4(6)/Version-2/I0462049054.pdf. 
Heni Noviarita, Roslee bin Ahmad, and Idzam Fautau

Sutrisno, Edy. 2016. Manajemen Sumber Daya Manusia. Jakarta: Kencana Prenada Media Group.

Wexley, Kenneth N, and Gary A Yukl. 1984. Organizational Behavior and Personnel Psychology. Homewood: R.D. Irwin. 